\title{
Coagulase-negative strains of Staphylococcus pyogenes
}

\author{
R. BAYSTON \\ From the Department of Bacteriology, Children's Hospital, Sheffield
}

SYNOPSIS The isolation of two coagulase-negative strains of Staphylococcus pyogenes is reported, and their biochemical characteristics are given. The reliability of coagulase tests alone in the identification of Staph. pyogenes is discussed, and the deoxyribonuclease test is recommended as a useful confirmatory test.

Two strains of staphylococci have recently been isolated in this laboratory, which had the biochemical characteristics of Staphylococcus pyogenes (BairdParker, 1963) but failed to produce either free or bound coagulase. Both strains were phage-typable using routine phages.

The first strain (A) was isolated from a hydrocephalic child of 3 months with a ventriculo-atrial shunt. It was suspected that she had septicaemia secondary to colonization of the shunt system, and blood cultures grew a staphylococcus which was coagulase-negative by both slide and tube methods. Sensitivity tests by the disc method (Multodisc, Oxoid) showed that the organism was sensitive to chloramphenicol and gentamycin, and resistant to penicillin, tetracycline, streptomycin, erythromycin, sulphonamides, and trimethoprim-sulphamethoxazol (Septrin). Further tests on salt agar showed that it was also resistant to methicillin. The organism was Received for publication 29 April 1971. again isolated from later blood cultures, from fluid aspirated from the Spitz-Holter valve, from the ventricular fluid, and from all the components of the shunt system after it had been removed.

The second strain (B) was isolated from the urine of a male patient aged 4 years who had had a small sacral meningocoele repaired. He was incontinent of urine, but otherwise normal. The organism was isolated from two consecutive specimens of urine. In each case there were between 20 and 25 white blood cells per high-power field in the centrifuged deposit and the organism was present as a heavy pure growth, the viable count being $10^{7}$ orgs $/ \mathrm{ml}$. This strain was resistant to penicillin only.

\section{Investigation of the Staphylococci}

All strains of coagulase-negative staphylococci isolated from lesions in this hospital are examined biochemically as part of a study of the problem of

\begin{tabular}{|c|c|c|c|}
\hline Test & Staph. pyogenes Subgroup SI & Strain A & Strain B \\
\hline Catalase & + & + & + \\
\hline Acid from glucose anaerobically & $\stackrel{+}{\text { Variable tunicollu }}$ & + & + \\
\hline $\begin{array}{l}\text { Pigment } \\
\text { Coagulase (see text) }\end{array}$ & $\begin{array}{l}\text { Variable, typically golden } \\
+\end{array}$ & Golden & Grey \\
\hline $\begin{array}{l}\text { Coagulase (see text) } \\
\text { Phosphatase production }\end{array}$ & $\begin{array}{l}+ \\
+\end{array}$ & - & - \\
\hline $\begin{array}{l}\text { Phosphatase production } \\
\text { Acetoin production }\end{array}$ & $\begin{array}{l}+ \\
+\end{array}$ & + & + \\
\hline $\begin{array}{l}\text { Acetoin production } \\
\text { Acid from arabinose }\end{array}$ & $\begin{array}{l}+ \\
-\end{array}$ & + & + \\
\hline $\begin{array}{l}\text { Acid from arabinose } \\
\text { Acid from galactose }\end{array}$ & $\overline{\text { Variable }}$ & - & - \\
\hline $\begin{array}{l}\text { Acid from galactose } \\
\text { Acid from inositol }\end{array}$ & $\begin{array}{l}\text { Variable } \\
\text { - }\end{array}$ & + & + \\
\hline Acid from inositol & & - & - \\
\hline & + (usually) & + & + \\
\hline Acid from maltose & + & + & + \\
\hline Acid from mannose & + & + & + \\
\hline Acid from salicin & - & - & - \\
\hline Acid from mannitol anaerobically & + (usually) & + & + \\
\hline Gelatin liquefaction & Variable & - & - \\
\hline DNA-se production & + & + & + \\
\hline Fibrinolysin production & + (usually) & + & + \\
\hline Phage type & & 77 & $52 / 52 \mathrm{~A} / 80 / 81$ \\
\hline
\end{tabular}

Table Comparison of characteristics of strains $A$ and $B$ with Staph. pyogenes 
shunt colonization, and the above organisms were included in this study because of the coagulase results. Biochemical tests indicated that both organisms belonged to subgroup SI (Staph. pyogenes) (Baird-Parker, 1963), and both organisms produced deoxyribonuclease (DNA-se), so attempts were then made to detect coagulase. First, the plasma was checked and found to give typical coagulation with control strains. Strains A and B were then inoculated into a series of $10 \%$ plasma broths kept at $37^{\circ} \mathrm{C}$, $30^{\circ} \mathrm{C}$, room temperature, and $+4^{\circ} \mathrm{C}$ for five days, the broths being examined daily. No clot was formed. The organisms were then inoculated onto plasmaagar plates (Lack, 1956) and incubated at $37^{\circ} \mathrm{C}$ for two days. A reduced zone about half the size of that of the control was produced. Neither strain produced more fibrinolysin than control organisms.

A culture of strain A was sent to Dr M. T. Parker at the Cross-Infection Reference Laboratory, Colindale, who kindly agreed to investigate the organism. Dr Parker's results indicated that the organism was Staph. pyogenes and confirmed that it was coagulase-negative. The results of biochemical and other investigations are summarized in Table I.

\section{Discussion}

Mutants of Staph. pyogenes resistant to one or more common antibiotics and which were coagulasenegative have been described previously (Klimek, Cavallito, and Bailey, 1948; McVeigh and Hobdy, 1952; Massieu, 1960). However, Brown and Evans (1963) found that their antibiotic-resistant strains were coagulase-positive and suggested that their strains arose as spontaneous mutants with genetic change affecting only loci pertaining to resistance, whereas the mutants described by other workers were produced as a result of exposure to toxic levels of antibiotics, ultraviolet irradiation, or chemical mutagens and probably suffered multiple genetic damage. One of the two strains described here, strain A, showed multiple resistance, but was capable of producing pigment, and generally had all the characteristics of Staph. pyogenes except, of course, production of coagulase. Other strains of methicillinresistant Staph. pyogenes isolated in this hospital have been coagulase-negative when tested by the slide test, but have produced free coagulase rapidly in the tube test. They have all belonged to phage type 77. Strain A is not known to have been exposed to mutagens of any sort, and was isolated before treatment was begun.

Until recently, coagulase production was the only criterion used in this laboratory for the identification of staphylococci as Staph. pyogenes. However, with the isolation of these two coagulase-negative strains, it became obvious that a confirmatory test was required.

Mannitol fermentation has been used by some workers to indicate pathogenicity (Mossel, 1962; Branson, 1968), but some coagulase-positive strains fail to attack this substrate (Mossel, 1962; Person, Yú, and Washington, 1969) and a few strains of the non-pathogenic subgroup SVI were found by BairdParker (1963) to ferment it. Members of this subgroup, and some micrococci, usually attack mannitol oxidatively, and anaerobic conditions are essential if media containing mannitol are to be used.

Tests for phosphatase production were recommended by Baird-Parker (1965) to be used in conjunction with coagulase tests, but his subgroups SII, SIII, and M6 produce phosphatase and thus a coagulase-negative strain of Staph. pyogenes could be wrongly identified as Staph. albus.

As both organisms gave small zones of opacity on plasma-agar plates, the use of these was considered. However, several anomalous results were obtained when the method was tested with various staphylococci, and it was decided that the plate-coagulase test was unsatisfactory for routine use.

The test for DNA-se production was found to be both more specific and more convenient in use. Brandish and Willis (1970) found that all coagulasepositive staphylococci isolated by them were DNA-se positive, and only two out of 596 coagulase-negative strains were positive. One of these was investigated in this laboratory and was found to belong to subgroup SIII (Baird-Parker, 1963). Similar results were obtained by other workers (Jacobs, Willis, and Goodburn), 1964; Jarvis and Wynne, 1968; Stickler, 1970).

All staphylococci isolated in this laboratory are now tested for DNA-se production as well as for coagulase production. A few strains of Staph. albus produce zones of clearing on the plates, but these zones are much smaller than those produced by Staph. pyogenes and are easily distinguished. It is suggested that this system provides a reliable safeguard against failure to recognise Staph. pyogenes and that this may apply particularly when multiple resistant strains are being examined.

My thanks are due to Professor M. G. McEntegart of the Department of Medical Microbiology, University of Sheffield, for valuable advice during the preparation of this paper, and to Mrs Maureen Sismey for typing the manuscript.

\section{References}

Baird-Parker, A. C. (1963). A classification of micrococci and staphylococci based on physiological and biochemical tests. J. gen. Microbiol., 30, 409-427. 
Baird-Parker, A. C. (1965). The classification of staphylococci and micrococci from world-wide sources. J. gen. Microbiol., 38, 363-387.

Brandish, J. M., and Willis, A. T. (1970). Observations on the coagulase and deoxyribonuclease tests for staphylococci. J. med. lab. Technol., 27, 355-358.

Branson, D. (1968). Identification of micrococcaceae in clinical bacteriology. Appl. Microbiol., 16, 906-911.

Brown, R. L., and Evans, J. B. (1963). Comparative physiology of antibiotic-resistant strains of Staphylococcus aureus. J. Bact., 85, 1409-1412.

Jacobs, S. I., Willis, A. T., and Goodburn, G. M. (1964). Pigment production and enzymatic activity of staphylococci: the differentiation of pathogens from commensals. J. Path. Bact., 87, 151156.

Jarvis, J. D., and Wynne, C. D. (1969). A short survey of the reliability of deoxyribonuclease as an adjunct in the determination of staphylococcal pathogenicity. J. Med. lab. Technol., 26, 131-133.
Klimek, J. W., Cavallito, C. J., and Bailey, J. H. (1948). Induced resistance of Staphylococcus aureus to various antibiotics. $J$. Bact., 55, 139-145.

Lack, C. H. (1957). Plate coagulase and fibrinolysin tests for staphylococci. J. clin. Path., 10, 208-210.

Massieu, M. S. (1960). Inhibition of plasma clotting ability in tetracycline resistant mutants of Staphylococcus aureus. J. Bact., $79,905$.

McVeigh, I., and Hobdy, C. J. (1952). Development of resistance by Micrococcus pyogenes var. aureus to antibiotics. Morphologica] and physiological changes. Amer. J. Bot., 39, 352-359.

Mossel, D. A. A. (1962). Attempt in classification of catalasepositive staphylococci and microcococci. J. Bact., 84, 11401147.

Person, D. A., Yú, P. K. W., and Washington, I. A. (1969). Characterisation of micrococcaceae isolated from clinical sources. $\mathrm{Appl}$. Microbiol., 18, 95-97.

Stickler, D. J. (1970). Some observations on the detection of staphylococcal deoxyribonuclease. J. Med. lab. Technol., 27, 83-85. 